\title{
Success Factors in Title III Equity Crowdfunding in the United States
}

\author{
Stanislav Mamonov \\ Montclair State University \\ stanislav.mamonov@montclair.edu
}

\author{
Ross Malaga \\ Montclair State University \\ ross.malaga@montclair.edu
}

\begin{abstract}
Title III of the JOBS Act took effect in May 2016 and it began a new chapter in equity crowdfunding in the United States by providing an opportunity for entrepreneurial ventures to solicit funding from nonaccredited investors. Due to the relative novelty, little is known about factors that can affect equity crowdfunding success under Title III. To address this gap in research, we draw on the risk capital framework and we examine the effects of market, execution and agency risks in equity crowdfunding under Title III. We collect data on 133 ventures that attracted more than $\$ 11$ million in funding commitments across sixteen Title III equity crowdfunding platforms. We find that all three types of risks can affect the likelihood of successful fundraising under Title III. We discuss the implications of these findings for entrepreneurs, investors, crowdfunding platforms and policy makers.
\end{abstract}

\section{Introduction}

Equity crowdfunding refers to the process of raising funds for entrepreneurial ventures, typically via Internet-based platforms, whereby investors receive equity in exchange for capital [42]. Equity crowdfunding is distinct from rewards-based crowdfunding. In rewards-based crowdfunding, project backers provide funds to early stage entrepreneurial projects, typically in exchange for a discount on the planned product, but receive no equity in the project. For example, Oculus Rift raised over \$2.4 million on Kickstarter [14], a rewardsbased crowdfunding platform, through pre-orders for the virtual reality headset, but the individual backers received no equity in the company and they did not benefit from the $\$ 2.3$ billion acquisition of the company by Facebook [11].

Equity crowdfunding was explicitly prohibited in the United States prior to the passage of the JOBS Act in 2012 [40]. The JOBS Act sought to make it easier for entrepreneurs to raise funding and it contains several provisions. Title II of the JOBS Act became effective in 2013 and it relaxed the rules concerning public investment solicitation from accredited investors [41]. Accredited investors are individuals who either have income exceeding $\$ 200,000$ per year or have at least $\$ 1$ million in assets, excluding the primary residence [39]. Preliminary research on Title II equity crowdfunding shows that over $\$ 1.4$ billion have been committed by accredited investors to Title II projects [26], however much less is known about Title III.

Title III of the JOBS Act expanded permissible equity crowdfunding to include the general public [18]. Title III allows companies to raise up to $\$ 1$ million from accredited and non-accredited investors over a 12-month period and it allows individual nonaccredited investors to commit up to $\$ 2,000$ a year to equity crowdfunded projects if the person's income is less than $\$ 100,000$ a year and up to $\$ 10,000$ if the person's income is above $\$ 100,000$ [18].

Investor participation in early stage venture financing exposes the investors to many risks [43]. Concerns about individual non-accredited investor protections delayed the implementation of Title III provisions until May 2016 [18]. A theoretical evaluation of Title III legislation suggested that Title III would likely fail due to information asymmetry and adverse selection problems [7], yet little is known about the actual state of affairs across Title III equity crowdfunding platforms. This is the research gap that we begin to address in the present study.

We analyze 133 projects across sixteen Title III equity crowdfunding platforms that sought to raise funding in the period between May 2016 and February 2017. In addition to providing empirical evidence that entrepreneurial ventures can be successful in raising funds under Title III, we also examine the effects of market, execution and agency risks on venture fundraising success in Title III equity crowdfunding. Our results reveal that all three types of risks can affect the success of fundraising in Title III platforms.

The remainder of the manuscript is structured as follows. First, we provide an overview of prior research on equity crowdfunding. Next, we draw on research in risk capital investments and we develop the research framework in our study. We then 
describe the data and our analytical methodology, and we present the results. We conclude with a discussion of emergent insights and implications of our findings for entrepreneurs, investors, crowdfunding platforms and policy makers.

\section{Equity crowdfunding literature review}

Equity crowdfunding is distinct from other types of crowdfunding that exist, in that it allows backers to receive an equity stake in the company. Generally, four types of crowdfunding are recognized: rewardsbased, equity-based, loan-based and donation-based. Rewards-based crowdfunding allows entrepreneurs to raise funding by enabling project backers to pre-order a product or service that is being developed. Rewards-based crowdfunding has always been legal in the United States, Famously, Joseph Pulitzer, the publisher of New York World, led a crowdfunding campaign to build the pedestal for the Statue of Liberty and successfully raised funding from 160,000 contributors in 1885 [36].

IndieGogo and KickStarter were among the first platforms to leverage the Internet to expand the reach of rewards-based crowdfunding and they have brokered over $\$ 3$ billion in funding commitments since launch [19]. There is an active stream of research exploring factors that affect the success of projects hosted on these platforms [22,31,32], however these studies do not necessarily yield useful insights for equity-based crowdfunding, because investor motivations for participation in equity-based crowdfunding platforms are very different from backers in rewards-based crowdfunding [5]. Equity investors are typically motivated by the expected gains in the value of their investments, as opposed to receiving a product or service from a rewards-based project.

Loan-based, also known as peer-to-peer (P2P), lending is the third type of crowdfunding. Platforms that facilitate $\mathrm{P} 2 \mathrm{P}$ lending, e.g. LendingClub, typically perform credit risk assessment on the requests for unsecured personal loans and they connect borrowers with potential lenders. The key difference between loan-based and equity-based crowdfunding is the risk/reward profile of the participating investors. $\mathrm{P} 2 \mathrm{P}$ lending typically involves relatively short-term loans (6-36 months), with a clearly defined interest rate that is set at the time of loan origination. Equity-based crowdfunding exposes the investors to much greater uncertainty in terms of both the time horizon for realizing a return on the investment, as well the likelihood of earning a financial return. Research on early stage venture investments suggests that it commonly takes 5-8 years for the investors in early stage entrepreneurial ventures to achieve liquidity and more than half of the investments in early stage ventures result in a loss of the invested capital [27].

Whereas the participation in equity, rewards, and loan-based crowdfunding is typically motivated by self-interest [5], there are also crowdfunding platforms, e.g. Kiva.org, that facilitate philanthropic activities. Donors on the Kiva platform provide funds to support entrepreneurs in developing countries. This activity is primarily altruistic - the donors have no financial incentives to participate on the platform. Table 1 summarizes the key differences between different types of crowdfunding.

Table 1. Capital provider motivations, risks and liquidity horizons across crowdfunding categories

\begin{tabular}{|l|l|l|l|l|}
\hline & $\begin{array}{l}\text { Donation- } \\
\text { based CF }\end{array}$ & $\begin{array}{l}\text { Rewards- } \\
\text { based CF }\end{array}$ & $\begin{array}{l}\text { Loan- } \\
\text { based } \\
\text { CF }\end{array}$ & $\begin{array}{l}\text { Equity- } \\
\text { bases CF }\end{array}$ \\
\hline $\begin{array}{l}\text { Capital } \\
\text { provider } \\
\text { motivation }\end{array}$ & Altruism & $\begin{array}{l}\text { Product } \\
\text { or service }\end{array}$ & $\begin{array}{l}\text { Earned } \\
\text { interest }\end{array}$ & $\begin{array}{l}\text { Equity } \\
\text { appreciation }\end{array}$ \\
\hline Risks & None & $\begin{array}{l}\text { Product } \\
\text { or service } \\
\text { not } \\
\text { delivered }\end{array}$ & $\begin{array}{l}\text { Loss of } \\
\text { principal }\end{array}$ & $\begin{array}{l}\text { Loss of } \\
\text { investment }\end{array}$ \\
\hline $\begin{array}{l}\text { Liquidity } \\
\text { horizon }\end{array}$ & $\begin{array}{l}\text { Not } \\
\text { applicable }\end{array}$ & $\begin{array}{l}\text { Not } \\
\text { applicable }\end{array}$ & $\begin{array}{l}6-36 \\
\text { months }\end{array}$ & 5-8 years \\
\hline
\end{tabular}

While equity crowdfunding is a relatively recent phenomenon in the United States, a number of other countries have had a head start. Equity crowdfunding has always been legal in Australia and the Australian Small Scale Offering Board (ASSOB) has helped entrepreneurs raise over $\$ 146$ million since its launch in 2005 [4]. Ahlers et al. [3] examined factors that influence equity crowdfunding success on ASSOB and found that provision of financial projections by the entrepreneurs and the entrepreneurs retaining a greater share of equity were positively associated with crowdfunding success.

Equity crowdfunding regulation has advanced rapidly in Europe and each country in the European Union has at least one equity crowdfunding platform [12]. Several studies have explored factors that can affect the success of equity crowdfunding on the European platforms. Lukkarinen et al. [25] examined an equity crowdfunding platform in Finland and found that the size of the entrepreneurs' social networks had a positive effect on the likelihood of successful fundraising, while the minimum investment amount required from each potential investor had a negative effect on the likelihood of success. Vismara $[45,46]$ explored success factors on Crowdcube, an equity crowdfunding platform based in the United Kingdom (UK) and found that social 
connections, equity retention and engagement of professional investors were positively associated with successful campaigns. Professional investor involvement was also identified as an important factor by Ralcheva and Roosenbloom who also studied Crowdcube [38].

Focusing on equity crowdfunding in the United States, Agrawal et al. [1] presented a theoretical analysis highlighting the potential for the crowdfunding platforms to amplify information asymmetries that commonly exist in early stage ventures. Entrepreneurs typically know more about the prospects of a business venture than the potential investors and the information asymmetry presents a challenge in the evaluation of investment opportunities. However, in a subsequent study, the authors found that angel investors often pool their resources and form syndicates, wherein a well-known investor takes the lead role in performing the due diligence on potential investments, thus providing a solution to the information asymmetry challenges [2]. Focusing on Title II equity crowdfunding platforms, Mamonov et al. [26] showed that real estate projects are particularly successful in raising funding from the accredited investors under Title II. Table 2 summarizes the insights of empirical studies that examined equity crowdfunding in different geographies.

Table 2. Empirical studies in equity CF

\begin{tabular}{|c|c|}
\hline Authors / Context & Insights \\
\hline $\begin{array}{l}\text { Ahlers et al. (2015) [3] } \\
\text { Australian Small Scale } \\
\text { Offering Board }\end{array}$ & $\begin{array}{l}\text { Provision of financial } \\
\text { projections and entrepreneurs } \\
\text { retaining greater equity } \\
\text { percentage are associated with } \\
\text { successful fundraising. }\end{array}$ \\
\hline $\begin{array}{l}\text { Lukkarinen et al. (2016) } \\
\text { [25] } \\
\text { Finland }\end{array}$ & $\begin{array}{l}\text { The size of the minimum } \\
\text { investment (negative effect) } \\
\text { and early finding from } \\
\text { entrepreneurs' private networks } \\
\text { are associated with successful } \\
\text { fundraising. }\end{array}$ \\
\hline $\begin{array}{l}\text { Vismara (2016) [45] } \\
\text { Crowdcube, UK }\end{array}$ & $\begin{array}{l}\text { Equity retention and number of } \\
\text { social connections in social } \\
\text { networking sites are predictive } \\
\text { of funding success. }\end{array}$ \\
\hline $\begin{array}{l}\text { Vismara (2016) [46] } \\
\text { Crowdcube, UK }\end{array}$ & $\begin{array}{l}\text { Engagement of well-known } \\
\text { investors has a positive effect } \\
\text { on project success. }\end{array}$ \\
\hline $\begin{array}{l}\text { Ralcheva and } \\
\text { Roosenbloom (2016) } \\
\text { [38] } \\
\text { Crowdcube, UK }\end{array}$ & $\begin{array}{l}\text { Professional investor } \\
\text { involvement and patents are } \\
\text { associated with success. }\end{array}$ \\
\hline $\begin{array}{l}\text { Catalini et al. (2016) [2] } \\
\text { Angel.co - Title II }\end{array}$ & $\begin{array}{l}\text { Syndicate driven investments } \\
\text { dominate the angel investor } \\
\text { oriented equity crowdfunding }\end{array}$ \\
\hline
\end{tabular}

\begin{tabular}{|l|l|}
\hline equity crowdfunding & platform. \\
\hline $\begin{array}{l}\text { Mamonov et al., (2017) } \\
{[26]}\end{array}$ & $\begin{array}{l}\text { Real estate investments are } \\
\text { disproportionately more } \\
\text { successful in Title II } \\
\text { crowdfunding. }\end{array}$ \\
$\begin{array}{l}\text { Title II equity } \\
\text { crowdfunding platforms }\end{array}$ & \\
\hline
\end{tabular}

\section{Research framework and hypotheses}

The goal of the present study is to understand factors that can impact the success of equity crowdfunding under Title III. Title III equity crowdfunding is open to both accredited and nonaccredited investors. While little is known about the criteria that may influence non-accredited investor decision making in this context, research has suggested that faced with the uncertainty of investment decisions, less knowledgeable investors often take their cues from experts [20]. We expect that in Title III equity crowdfunding less sophisticated investors will follow the lead of business angels (accredited investors) who are also active in Title III equity crowdfunding platforms. Hence, we draw on research focusing on business angel investor decision making to develop the theoretical framework in our study.

Research has shown that investors in informal risk capital markets focus on risks that fall into three general categories: market risk, execution risk and agency risk [6]. Market risk is the risk of losing money on an investment due to overall market factors. Examples of market factors include competition, recession, political turmoil, and growth potential. Many of these risks are external to the venture and outside the entrepreneur's control. However, prior research has shown that market risk is the top reason why professional angel investor groups reject an investment $[6,28]$. When analyzing market risk, investors typically consider the stage of the venture in question. Market risk is reduced as the venture proceeds from idea/concept to prototype to actual sales.

A venture that is just in the idea/concept phase has the most market risk because its market potential has not been proven. As the venture moves from the idea/concept stage to the prototype/minimal viable product stage some uncertainty about the product is removed. However, the market risk still remains high.

A venture needs to show that its product/service can succeed in the market. It can accomplish this by selling its product/service directly to consumers for a business-to-consumer (B2C) venture or signing corporate customers for a business-to-business (B2B) venture [13]. Successful consumer product launches and signings of marquee corporate clients are 
commonly interpreted by risk capital investors as market validation [28] and we expect a similar behavior among the investors in the context of equity crowdfunding platforms.

H1a. Ventures that completed product/service development are more likely to raise funding in online equity crowdfunding campaigns than early stage ventures (ideas and prototypes).

H1b. Ventures that have large corporate clients are more likely to raise funding in online equity crowdfunding campaigns than ventures lacking such clients.

Prior research has shown that investors consider whether the venture represents a disruptive or incremental innovation as a criterion for providing funding [29]. Startups that offer only incremental innovations are unlikely to succeed in competition with established incumbents. This is due to the fact that incumbents typically have greater resources (i.e., financial, marketing, $\mathrm{R} \& \mathrm{D}$, etc.) than startups and can react aggressively to incremental innovation. For example, the incumbent can accelerate their R\&D cycle to develop and market a similar or superior incremental innovation [21].

Startups based on a disruptive innovation are more likely to attract funding [9]. While not a perfect proxy for disruptive innovation, patents provide strong evidence of significant practical innovation [15]. Patents also provide protection for startups from potential imitation by incumbents and thus they can offer a source of sustainable competitive advantage.

H2. Ventures that hold patents are more likely to raise funding in online equity crowdfunding campaigns than ventures that do not have patents.

Execution risk is the risk that a venture's business plans will not succeed in the market. In order to execute their plans successfully, startup ventures require a diverse portfolio of skills, such as, product development, marketing, operations, financial management, etc. [24]. No individual entrepreneur is likely to possess all of the skills required to make the venture a success. Prior research indicates that venture capitalists are more likely to invest in startup teams over single entrepreneurs [17]. In addition, venture capitalists prefer teams that are comprised of both young entrepreneurs with new ideas and more seasoned executives who can guide the venture to successful execution of its plans [17].

Research has shown that angel investors consider an entrepreneur's prior industry experience and prior entrepreneurial experience when deciding whether to invest [28]. Potential investors value prior entrepreneurial experience due to the fact that in order to realize financial reward from an early stage investment the venture must have an "exit" (buyout or public offering). Entrepreneurs who have had previous successful exits understand the expectations of investors and have shown their ability to deliver financial rewards.

H3a. Single entrepreneurs are less likely to successfully raise funding in online equity crowdfunding campaigns than entrepreneurial teams comprised of 2 or more members.

H3b. Serial entrepreneurs are more likely to successfully raise funding in online equity crowdfunding campaigns.

H3c. Entrepreneurs with prior experience in the target industry are more likely to raise funding in online equity crowdfunding campaigns.

H3d. Larger entrepreneurial teams are more likely to successfully raise funding in online equity crowdfunding campaigns.

The information asymmetry between the entrepreneurs and potential investors leads to agency risk. Entrepreneurs know more about their business than potential investors. This can lead to opportunism which is more common among younger, smaller firms [37]. Angel investors typically mitigate the agency risk by close involvement in the entrepreneurial ventures in which they invest. However, online platform-mediated investments allow for more geographically distant investments which makes active angel investor engagement in the entrepreneurial ventures very challenging [34]. In these cases, potential investors might rely on another angel investor or $\mathrm{VC}$ firm to take a lead role in closely monitoring the venture. Research conducted on the angel-oriented, equity crowdfunding platform Angel.co has shown that successful fundraising is dominated by syndicate-based investments. In this structure a well-known angel investor or VC takes the lead role - providing due diligence and close monitoring [2]. Therefore, we anticipate that companies that have funding from an experienced angel or $\mathrm{VC}$ are more likely to attract further funding from investors on equity crowdfunding platforms.

H4a. Ventures that have already attracted funding from established angel investors would be more likely to successfully raise funding in online equity crowdfunding campaigns.

H4b. Ventures that have already attracted funding from professional venture capital firms would be more likely to successfully raise funding in online equity crowdfunding campaigns.

Characteristics of the entrepreneur have been shown to be an important screening factor for angel 
and VC investors [8]. For example, prior research has noted the importance of entrepreneurial passion and determination as well as trustworthiness in successful venture fundraising [35]. Entrepreneurs that do not show passion and determination undermine investor confidence that the entrepreneur can overcome the many challenges faced in shepherding a venture to success and then an exit. Investors also want to feel that the entrepreneur will be a trustworthy steward of any money invested [28]. Entrepreneurs may find it challenging to communicate their various positive characteristics to investors in a computer-mediated context. Prior research in rewards-based crowdfunding has shown that video is an important communication tool in computer-mediated communication [31]. We expect that successful entrepreneurs will make use of video in communicating with potential investors in equity crowdfunding platforms.

H5a. Ventures that use video in their project descriptions will be more likely to successfully raise funding in online equity crowdfunding campaigns.

H5b. Ventures that use video featuring the founders in their project descriptions will be more likely to successfully raise funding in online equity crowdfunding campaigns.

\section{Data and methodology}

We obtained the dataset for our study by collecting project-level details across sixteen Title III equity crowdfunding platforms. We collected project descriptions as well as the information about the amount of capital sought and funds committed by the investors to each project. Appendix A provides a summary of the number of projects and total capital commitments for each of the platforms in our dataset.

Project success is the dependent variable in our study. Following the accepted practice [3], we defined project success, as a venture raising the minimum amount of capital that was sought. 69 of $133(51.9 \%)$ projects in our dataset were successful in achieving their funding goals.

We engaged two graduate assistants with experience in entrepreneurship and equity crowdfunding to review the project descriptions and code the data. The coders met with the authors to resolve coding differences. Table 3 summarizes the independent variable and co-variate coding schema and it also provides the descriptive statistics for the data in our study.

To assess the effects of the independent variables on the project equity crowdfunding success we ran a series of logistic regression models. We relied on
SPSS version 22 to conduct the analysis. In the next section, we discuss the results.

Table 3. Variable coding schema and descriptive statistics

\begin{tabular}{|c|c|}
\hline Variable name / Coding schema & $\begin{array}{l}\text { Descriptive } \\
\text { statistics }\end{array}$ \\
\hline $\begin{array}{l}\text { Single_entrepreneur } \\
1 \text { - single entrepreneur } \\
0 \text { - otherwise }\end{array}$ & $\begin{array}{l}21.8 \% \text { of the } \\
\text { ventures were led } \\
\text { by a single } \\
\text { entrepreneur }\end{array}$ \\
\hline $\begin{array}{l}\text { Industry_experience } \\
\text { Founder(s) have experience in the } \\
\text { target industry: } \\
1 \text { - yes, } 0 \text { - no }\end{array}$ & $\begin{array}{l}95.5 \% \text { of the } \\
\text { ventures had } \\
\text { founders with } \\
\text { industry experience } \\
\text { in the target } \\
\text { industry }\end{array}$ \\
\hline $\begin{array}{l}\text { Serial_entrepreneur } \\
\text { At least one of the founders has prior } \\
\text { entrepreneurial experience: } \\
1-\text { yes, } 0 \text { - no }\end{array}$ & $\begin{array}{l}9 \% \text { of the ventures } \\
\text { were led by serial } \\
\text { entrepreneurs }\end{array}$ \\
\hline $\begin{array}{l}\text { Team_size } \\
\text { The number of people involved in } \\
\text { the venture. }\end{array}$ & $\begin{array}{l}\text { Min }=1 \\
\text { Max }=22 \\
\text { Average }=3.9 \\
\text { St. dev }=2.5\end{array}$ \\
\hline $\begin{array}{l}\text { Venture_stage } \\
\text { Idea-venture is at the idea/concept } \\
\text { stage } \\
\text { Beta - a beta or a prototype has been } \\
\text { developed } \\
\text { Product - the product or service has } \\
\text { been developed and it is offered to } \\
\text { potential clients }\end{array}$ & $\begin{array}{l}\text { Idea }=5 \\
\text { Beta }=65 \\
\text { Product }=63\end{array}$ \\
\hline $\begin{array}{l}\text { Angel_investors } \\
1 \text { - the company has received } \\
\text { funding from a professional angel } \\
\text { investor } \\
0-\text { none }\end{array}$ & $\begin{array}{l}19.5 \% \text { of the } \\
\text { ventures in our } \\
\text { dataset had } \\
\text { received funding } \\
\text { from professional } \\
\text { angel investors } \\
\end{array}$ \\
\hline $\begin{array}{l}\text { VC_investment } \\
1-\text { the company has received } \\
\text { funding from a venture capital firm } \\
0-\text { none }\end{array}$ & $\begin{array}{l}18 \% \text { of the } \\
\text { ventures in our } \\
\text { dataset had } \\
\text { received funding } \\
\text { from VC investors }\end{array}$ \\
\hline $\begin{array}{l}\text { Video } \\
1 \text { - venture description contains a } \\
\text { video } \\
0 \text { - none }\end{array}$ & $\begin{array}{l}84.9 \% \text { of the } \\
\text { venture funding } \\
\text { solicitations } \\
\text { included a video }\end{array}$ \\
\hline $\begin{array}{l}\text { Entrepreneur_video } \\
1 \text { - founder(s) appears in the video } \\
0-\text { the founder(s) is not in the video }\end{array}$ & $\begin{array}{l}60.15 \% \text { of the } \\
\text { solicitations } \\
\text { included a video } \\
\text { that featured the } \\
\text { founder(s) }\end{array}$ \\
\hline $\begin{array}{l}\text { Patents_issued } \\
1-\text { the company has received } \\
\text { patents }\end{array}$ & $\begin{array}{l}12.8 \% \text { of the } \\
\text { ventures had } \\
\text { obtained patents }\end{array}$ \\
\hline
\end{tabular}




\begin{tabular}{|l|l|}
\hline $0-$ none & \\
\hline Minimum issue amount & Min: $\$ 10,000$ \\
& Max: $\$ 15$ mil \\
The minimum amount of funding & Mean: $\$ 349,307$ \\
sought by the venture, in \$ & Mode: $\$ 100,000$ \\
& St. dev.: $\$ 1.3 \mathrm{mil}$ \\
\hline
\end{tabular}

\section{Results}

In the first step of our analysis, we examined separate effects of market, execution, agency and computer-mediation effects on the likelihood of venture success in raising funding in online Title III equity crowdfunding platforms.

Focusing on the market risks, we found that the company development stage had an effect on the success of a crowdfunding campaign. Companies in the beta/prototype stage were less likely to raise funding $(\mathrm{B}=-0.84, \mathrm{p}<0.05)$ than companies that completed product development. There was no statistically significant effect for the companies in the "idea" stage. This is likely due to the fact that there were only 5 such companies in our dataset. We also found a significant positive effect of a company having corporate clients in its portfolio $(\mathrm{B}=0.88$, $\mathrm{p}<0.05$ ). These results lend support for $\mathrm{H} 1 \mathrm{a}$ and $\mathrm{H} 1 \mathrm{~b}$. Although $12.9 \%$ of the companies in our dataset held patents, we found no statistically significant effects of the patents on the likelihood of successful equity crowdfunding. $\mathrm{H} 2$ was not supported. The results are shown in Model 1 column in Table 4.

Focusing on the execution risks, we found a statistically significant negative effect for singleentrepreneur led ventures $(B=-1.15, \mathrm{p}<0.05)$ and a statistically significant positive effect for the size of the entrepreneurial team $(\mathrm{B}=0.251, \mathrm{p}<0.01)$. These results provide support for $\mathrm{H} 3 \mathrm{a}$ and $\mathrm{H} 3 \mathrm{~d}$. We found no support for the effects of prior industry experience or serial entrepreneurial experience on the success of equity crowdfunding in our data. $\mathrm{H} 3 \mathrm{~b}$ and $\mathrm{H} 3 \mathrm{c}$ were not supported. The results are shown in Model 2 column in Table 4.

Next, we examined the effects of professional investor involvement in the mitigation of agency risks that commonly exist in early stage ventures. We found that when examined individually, both professional angel investor involvement $(B=1.6$, $\mathrm{p}<0.01)$ and venture capitalist participation $(B=2.6$, $\mathrm{p}<0.001)$ were positively associated with the success in equity crowdfunding, however only VC participation was statistically significantly correlated with the likelihood of success in the model that included both factors. The results provide support for $\mathrm{H} 4 \mathrm{a}$ and H4b. Model 3 column in Table 4 provides the summary of effects.
Finally, we assessed the full model that included market, execution and agency risks as well as the use of video to communicate with the potential investors in equity crowdfunding platforms. We found that in the full model the company stage, the size of the entrepreneurial team, professional angel investor and $\mathrm{VC}$ involvement retained their effects on the success of equity crowdfunding under Title III. These results remain significant after controlling for the size of the investment required by the companies and the month when the fundraising campaign was launched. The results are summarized in the Full model column in Table 4.

Table 4. The effects of market, execution and agency risks in Title III equity crowdfunding

\begin{tabular}{|c|c|c|c|c|}
\hline & $\begin{array}{l}\text { Model } \\
1: \\
\text { Market } \\
\text { risk }\end{array}$ & $\begin{array}{l}\text { Model } \\
2: \\
\text { Executio } \\
n \text { risk }\end{array}$ & $\begin{array}{l}\text { Model } \\
3: \\
\text { Agenc } \\
\text { y risk }\end{array}$ & $\begin{array}{l}\text { Full } \\
\text { model }\end{array}$ \\
\hline \multicolumn{5}{|l|}{ Company stage } \\
\hline idea & ns & & & ns \\
\hline $\begin{array}{c}\text { beta / } \\
\text { prototype }\end{array}$ & $-0.84 *$ & & & $-0.78 *$ \\
\hline \multicolumn{5}{|l|}{ product } \\
\hline Corporate clients & $0.88 *$ & & & $1.05 *$ \\
\hline Patents & ns & & & ns \\
\hline $\begin{array}{l}\text { Single } \\
\text { entrepreneur }\end{array}$ & & $-1.15^{*}$ & & $-1.26 *$ \\
\hline $\begin{array}{l}\text { Serial } \\
\text { entrepreneur }\end{array}$ & & ns & & ns \\
\hline $\begin{array}{l}\text { Industry } \\
\text { experience }\end{array}$ & & ns & & ns \\
\hline Team size & & $0.251 *$ & & $0.25^{*}$ \\
\hline Angel investors & & & $\mathrm{ns}$ & $0.98 *$ \\
\hline VC investors & & & $2.3^{* *}$ & $2.14^{*}$ \\
\hline Video & & & & ns \\
\hline $\begin{array}{l}\text { Entrepreneur in } \\
\text { video }\end{array}$ & & & & ns \\
\hline $\begin{array}{l}\ln (\text { Minimum } \\
\text { issue amount) }\end{array}$ & & & & $-0.89 * * *$ \\
\hline $\begin{array}{l}\text { Campaign start } \\
\text { month }\end{array}$ & & & & ns \\
\hline$-2 \log$ likelihood & 164.2 & 168.2 & 158 & 113.2 \\
\hline Cox \& Snell R ${ }^{2}$ & 0.14 & 0.106 & 0.178 & 0.408 \\
\hline Nagelkerke $\mathrm{R}^{2}$ & 0.19 & 0.141 & 0.238 & 0.537 \\
\hline
\end{tabular}

Unobserved project-level heterogeneity is a common concern in panel data analysis [33]. To assess the potential effects of unobserved heterogeneity we reanalyzed the full model using the mixed logit technique which accounts for the potential subpopulations in the data [16]. The results 
of the mixed logit model affirmed the effects of the company stage, corporate clients, entrepreneurial team size and single entrepreneur led ventures as well the involvement of professional angel investors and venture capitalists on the success of equity crowdfunding under Title III.

\section{Discussion and implications 6.1. Discussion}

In this study, we argued that less sophisticated non-accredited investors in Title III equity crowdfunding platforms would follow the more sophisticated investors' lead. We drew on the risk capital framework and we evaluated the effects of market, execution and agency risks that are commonly considered by professional angel investors in traditional offline investments. Our results show that all three types of risks have an effect on the likelihood of a successful equity crowdfunding campaign in online Title III equity crowdfunding platforms. However, not all variables that we examined had an effect.

In terms of market risks, we found that ventures that progressed to the product/service stage were more likely to be successful in raising funding in Title III platforms. $65 \%$ of the ventures in the product/service stage were successful, whereas only $43 \%$ of the ventures in the beta/prototype stage were successful. None of the five ventures in the idea stage was successful in achieving the funding goal. These results indicate that investors in Title III platforms are willing to consider companies in the beta/prototype stage of development, however the companies that progressed to the product/service stage are more likely to achieve their funding goals. We also found that while patents had no statistically significant effect on the likelihood of success, market traction evidenced in a company having corporate customers had a significant positive effect. $70.3 \%$ of companies that had corporate customers were successful in raising funding in Title III platforms that we examined.

Focusing on the execution risk, we found that single entrepreneur ventures were successful only $33.3 \%$ of the time in reaching the funding goal, whereas ventures with entrepreneurial teams were successful $53.2 \%$ of the time. The importance of entrepreneurial teams versus single entrepreneurs is consistent with the insights from research on angel investor decision making $[6,44]$, however we found no support for prior entrepreneurial experience or industry experience effects on investment decisions.

In our evaluation of agency risks in Title III crowdfunding, we focused on whether engagement of professional angel investors and/or venture capitalists is associated with a higher probability of successful equity crowdfunding. We found that both angel investor and VC participation had significant effects. $80.8 \%$ of ventures that received funding from a prominent angel investor prior to soliciting funding via equity crowdfunding were successful. $91.7 \%$ of companies that received funding from a venture capital firm prior to the engagement in equity crowdfunding platforms were successful in hitting their funding targets.

We also examined whether the use of video could help entrepreneurs overcome the challenges of communicating their passion and commitment to the success of the ventures to potential investors. Contrary to results from rewards-based crowdfunding [30], we found no significant effect for the use of video in investment solicitations. Unfortunately, our data does not yield clues as to why the use of video had no effect and further research will be required to understand how entrepreneurs can leverage rich media in communicating with investors in equity crowdfunding platforms.

To evaluate the robustness of our model, we examined the effect of incorporating the funding goal amount and the month in which the equity crowdfunding campaign was launched on the likelihood of crowdfunding success as covariates in our model. The effects of the key variables in our model remained significant after the addition of these covariates to the model. Consistent with prior research in equity crowdfunding [45], we found a negative effect of the funding goal amount on the likelihood of a campaign's success in our data. Further examination of the data revealed that 46 of 133 ventures $(35.4 \%)$ sought to raise less than $\$ 100,000$ and $70 \%$ of these ventures were successful in raising the target capital. Whereas ventures seeking more than $\$ 500,000$ were successful only $33.4 \%$ of the time, and none of the ventures that sought to raise over \$1 million was successful.

In aggregate, our results suggest that investors in Title III crowdfunding platforms generally share their approach to potential investment evaluation with the professional angel investors. We find that investors in these platforms are perceptive to market, execution and agency risks. The investors prefer to fund companies that are headed by entrepreneurial teams (as opposed to a single entrepreneur). The investors also prefer companies that completed product or service development and are showing market traction by signing corporate customers. Our results also indicate that investors in Title III equity crowdfunding platforms are looking for external validation of the ventures seeking funding and 
management of agency risks in the form of traditional angel investor or VC involvement. These results imply that although Title III platforms are aimed at the less sophisticated non-accredited investors, the apparent patterns of investor decision making suggest that sophisticated investors play a key role in influencing the success of individual campaigns.

\subsection{Contributions to theory}

Our study makes a number of contributions to both theory and practice. Our first theoretical contribution is the adoption of the risk capital framework that was developed in the offline context [6] for the analysis of factors that can affect online venture equity crowdfunding success. The risk capital framework complements signaling and social capital perspectives that have been applied in studies of equity crowdfunding $[3,10]$. The risk perspective recognizes that understanding how investors evaluate potential investment opportunities is critical to entrepreneurs securing an investment. The risk perspective focuses on actual risk evaluation, whereas the signaling perspective addresses the question of how entrepreneurs can signal the fitness of their ventures to potential investors. Actual risks and what entrepreneurs may be able to signal to potential investors are distinct and therefore there is a need to understand the fundamental risks inherent to early stage ventures and how these risks affect investment decision in equity crowdfunding.

Our second theoretical contribution stems from provision of empirical evidence that shows that investors in Title III equity crowdfunding platform share their approach to investment evaluation with traditional offline business angel investors. These results suggest that while the Title III goal was to open access to early stage venture investments to non-accredited investors, it is the sophisticated and likely accredited investors who play the critical role in venture fundraising success under Title III. These results contribute to the emerging stream of evidence on the importance of experts in equity crowdfunding decisions [20] and suggest that such behavior may reflect rational herding [47] wherein less sophisticated investors follow the lead of the more experienced business angels.

\subsection{Implications for practice}

Our findings also have implications for entrepreneurs and operators of the crowdfunding platforms as well as policy makers. The empirical insights emergent from our study suggest that Title III equity crowdfunding platforms can be a source of early capital for entrepreneurial ventures, however the amount of available capital tends to be relatively low - less than $\$ 1$ million and more commonly less than $\$ 300,000$. Given the relatively low amount of capital that can be raised in Title III platforms, these platforms are likely to be supplementary sources of funding for entrepreneurs. In other words, entrepreneurs seeking seed (typically $\$ 500,000-\$ 1$ million) or series A (typically $\$ 1-\$ 5$ million) funding, would likely need to engage with traditional angel investors as the primary source of funds and then possibly augment the fundraising via a Title III campaign.

These observations also have implications for the operators of the Title III equity crowdfunding platforms. Provided that, at least at the moment, Title III platforms would be unlikely to serve as a singular source of seed or series A funds for new ventures, the platforms would benefit from close alignment with established angel investors and early stage venture capitalists in order to generate deal flow and sustain interest from potential non-accredited investors. In fact, WeFunder, the most successful platform in our dataset, emerged from Y Combinator, one of the best known venture accelerator programs that has a strong VC network [23].

Equity crowdfunding remains a hotly debated policy topic and Title III has received a fair share of criticism for coming up short in solving the challenge of easier access to funding for entrepreneurial ventures while also assuring investor protection $[7,43]$. The results of our study indicate that while Title III had a slower start compared to Title II [26], legislation has been adopted in practice and Title III equity crowdfunding platforms are gaining traction.

\subsection{Limitations}

While we collected data across all known Title III equity crowdfunding platforms, out dataset contains only 133 venture listings. It is known that several of the platforms included in our dataset remove unsuccessful campaigns from their sites, thus potentially biasing our results. However, our dataset does reflect the historical information that is actually available to potential investors on Title III platforms and 64 of $133(48.1 \%$ ) ventures did not reach the full target amount affording us an opportunity to examine the factors associated with fundraising success under Title III. Further research will be needed to reevaluate the insights that emerged in our study as Title III platforms continue to develop. 


\section{Conclusion}

In this study, we sought to address the lack of knowledge on the success factors in equity crowdfunding open to non-accredited investors in the United States under Title III of the JOBS Act. We argued that because Title III platforms are open to both non-accredited and accredited investors, the accredited investors would lead the way and they would leverage established practices in investment evaluation by examining market, execution and agency risks associated with early stage venture investments. We examined the role of these factors using a dataset collected across sixteen Title III equity crowdfunding platforms. Our results indicate that investors in Title III platforms are cognizant of market, execution and agency risks, but they are also selective in which factors they consider. We found that ventures started by teams of entrepreneurs, which progressed to product/service development, signed corporate clients, and received funding from professional investors were more likely to be successful in raising funding in Title III equity crowdfunding platforms. The results suggest that Title III platforms complement, rather than replace the professional investor funding for entrepreneurial ventures.

\section{Appendix A}

Title III equity crowdfunding platforms

\begin{tabular}{|l|r|r|}
\hline Platform & $\begin{array}{l}\text { Number of } \\
\text { projects }\end{array}$ & $\begin{array}{l}\text { Total capital } \\
\text { commitments }\end{array}$ \\
\hline Crowdsourcefunded & 2 & 0 \\
\hline Crudefunders.com & 1 & 112,950 \\
\hline Dreamfunded.vc & 1 & 0 \\
\hline Flashfunders.com & 8 & 138,188 \\
\hline iBankers & 2 & 0 \\
\hline Jumpstartmicro & 4 & 5,200 \\
\hline Localstake & 1 & 14,000 \\
\hline Netcapital & 2 & 13,925 \\
\hline Nextseed.co & 7 & $1,295,400$ \\
\hline Republic & 4 & 185,502 \\
\hline Seedinvest.com & 5 & 291,613 \\
\hline Startengine.com & 17 & $1,318,732$ \\
\hline Trucrowd & 5 & 37,333 \\
\hline uFundingportal & 18 & 30 \\
\hline Centure.co & 4 & 46,002 \\
\hline Wefunder & 43 & $7,857,725$ \\
\hline
\end{tabular}

\section{References}

[1] Agrawal, A., Catalini, C., and Goldfarb, A. Some simple economics of crowdfunding. National Bureau of Economic Research, 2013.

[2] Agrawal, A., Catalini, C., and Goldfarb, A. Are Syndicates the Killer App of Equity Crowdfunding? California Management Review 58, 2 (2014), 111125.

[3] Ahlers, G.K.C., Cumming, D., Günther, C., and Schweizer, D. Signaling in Equity Crowdfunding. Entrepreneurship Theory and Practice 39, 4 (2015), 955-980.

[4] ASSOB. About ASSOB. 2017.

https://assob.com.au/about.asp?page $=1$.

[5] Belleflamme, P., Lambert, T., and

Schwienbacher, A. Crowdfunding: Tapping the right crowd. Journal of Business Venturing 29, 5 (2014), 585-609.

[6] Carpentier, C. and Suret, J.M. Angel group members' decision process and rejection criteria: A longitudinal analysis. Journal of Business Venturing 30, 6 (2015), 808-821.

[7] Catalini, C., Fazio, C., and Murray, F. Can equity crowdfunding democratize access to capital and investment opportunities? (2016), 1-16.

[8] Chen, X.-P., Yao, X., and Kotha, S. Entrepreneur passion and preparedness in business plan presentations: a persuasion analysis of venture capitalists' funding decisions. Academy of Management journal 52, 1 (2009), 199-214.

[9] Christensen, C.M., Johnson, M.W., and Rigby, D.K. Foundations for growth: How to identify and build disruptive new businesses. MIT Sloan Management Review 43, 3 (2002), 22.

[10] Colombo, M.G., Franzoni, C., and RossiLamastra, C. Internal social capital and the attraction of early contributions in crowdfunding.

Entrepreneurship: Theory and Practice, (2014), 75101.

[11] Constine, J. Facebook's \$2 Billion Acquisition Of Oculus Closes, Now Official. Techcrunch, 2014. https://techcrunch.com/2014/07/21/facebooksacquisition-of-oculus-closes-now-official/.

[12] CrowdfundingHub. Current State of Crowdfunding in Europe. 2016.

[13] Feld, B. and Mendelson, J. Venture Deals: Be Smarter Than Your Lawyer and Venture Capitalist. John Wiley \& Sons, 2016.

[14] Gleasure, R. and Feller, J. A rift in the ground: Theorizing the evolution of anchor values in crowdfunding communities through the oculus rift case study. Journal of the Association of Information Systems 17, 10 (2016), 708-736.

[15] Häussler, C., Harhoff, D., and Müller, E. To Be 
Financed or Not...-The Role of Patents for Venture Capital-Financing. SSRN, 1393725 (2012).

[16] Hensher, D.A. and Greene, W.H. The mixed logit model: the state of practice. Transportation 30, 2 (2003), 133-176.

[17] Hsu, D.H. Experienced entrepreneurial founders, organizational capital, and venture capital funding.

Research Policy 36, 5 (2007), 722-741.

[18] Ivanov, V. and Knyazeva, A. U.S. Securitiesbased Crowdfunding Under Title III of the JOBS Act . 2017.

[19] KickStarter. KickStarter Statistics. 2017. https://www.kickstarter.com/help/stats.

[20] Kim, K. and Viswanathan, S. The experts in the crowd: The role of reputable investors in a crowdfunding market. The 41st Research Conference on Communication, Information and Internet Policy, (2014).

[21] Kuester, S., Homburg, C., and Robertson, T.S. Retaliatory behavior to new product entry. The Journal of Marketing, (1999), 90-106.

[22] Kuppuswamy, V. and Bayus, B.L. Does my contribution to your crowdfunding project matter? Journal of Business Venturing 32, 1 (2017), 72-89. [23] Lawler, R. Y Combinator-Backed WeFunder Launches To Bring Crowdfunding Startups To The Masses. Techcrunch, 2013. https://techcrunch.com/2013/03/19/wefunder-launch/. [24] Lazear, E.P. Balanced skills and entrepreneurship. The American Economic Review 94, 2 (2004), 208-211.

[25] Lukkarinen, A., Teich, J.E., Wallenius, H., and Wallenius, J. Success drivers of online equity crowdfunding campaigns. Decision Support Systems 87, (2016), 26-38.

[26] Mamonov, S., Malaga, R., and Rosenblum, J. An exploratory analysis of Title II equity crowdfunding success. Venture Capital, (2017), 118.

[27] Mason, C.M. and Harrison, R.T. Measuring business angel investment activity in the United Kingdom: a review of potential data sources. Venture Capital 10, 4 (2008), 309-330.

[28] Maxwell, A.L., Jeffrey, S.A., and Lévesque, M. Business angel early stage decision making. Journal of Business Venturing 26, 2 (2011), 212-225.

[29] Metrick, A. and Yasuda, A. Venture capital and the finance of innovation. (2010).

[30] Mollick, E. The dynamics of crowdfunding: Determinants of success and failure. Available at SSRN 2088298, (2012).

[31] Mollick, E. The dynamics of crowdfunding: An exploratory study. Journal of Business Venturing 29, 1 (2014), 1-16.

[32] Mollick, E. and Nanda, R. Wisdom or Madness?
Comparing Crowds with Expert Evaluation in Funding the Arts. Management Science 62, 6 (2016), 1533-1553.

[33] Mood, C. Logistic regression: Why we cannot do what We think we can do, and what we can do about it. European Sociological Review 26, 1 (2010), 67-82.

[34] Morrissette, S.G. A profile of angel investors. The Journal of Private Equity 10, 3 (2007), 52-66. [35] Murnieks, C.Y., Cardon, M.S., Sudek, R., White, T.D., and Brooks, W.T. Drawn to the fire: The role of passion, tenacity and inspirational leadership in angel investing. Journal of Business Venturing 31, 4 (2016), 468-484.

[36] National Park Service. Joseph Pulitzer. 2016. https://www.nps.gov/stli/learn/historyculture/josephpulitzer.htm.

[37] Noe, T.H. and Rebello, M.J. Asymmetric information, managerial opportunism, financing, and payout policies. The Journal of Finance 51, 2 (1996), 637-660.

[38] Ralcheva, A. and Roosenboom, P. On the Road to Success in Equity Crowdfunding On the Road to Success in Equity Crowdfunding. Available on SSRN, (2016), 1-23.

[39] SEC. Investor Bulletin: Accredited Investors. SEC's Office of Investor Education and Advocacy, 2013. https://www.investor.gov/news-alerts/investorbulletins/investor-bulletin-accredited-investors. [40] SEC. Jumpstart Our Business Startups (JOBS) Act. SEC Web site, 2015.

https://www.sec.gov/spotlight/jobs-act.shtml. [41] SEC. SEC Adopts Rules to Permit Crowdfunding. 2015. SEC Adopts Rules to Permit Crowdfunding.

[42] SEC. Investor Bulletin: Crowdfunding for Investors. Investor Alerts and Bulletins, 2016. https://www.sec.gov/oiea/investor-alertsbulletins/ib_crowdfunding-.html. [43] Siegel, B.P. Title III of the Jobs Act: Using Unsophisticated Wealth To Crowdfund Small Business Capital or Fraudsters' Bank Accounts? Hofstra Law Review 41, 3 (2013), 777-809.

[44] Sudek, R. Angel investment criteria. Journal of Small Business Strategy 17, 2 (2006), 89.

[45] Vismara, S. Equity retention and social network theory in equity crowdfunding. Small Business Economics 46, 4 (2016), 579-590.

[46] Vismara, S. Information cascades among investors in equity crowdfunding. Entrepreneurship Theory and Practice, (2016).

[47] Zhang, J. and Liu, P. Rational Herding in Microloan Markets. Management Science 58, 5 (2012), 892-912. 